\title{
Obóz dla dipisów - literackie zapisy doświadczenia życia ,pomiędzy" Zaproszenie do tematu
}

Krajobraz po bitwie (1970) Andrzeja Wajdy otwiera ciekawy wizualnie, jakby pospiesznie filmowany pejzaż obozu, odbijający się w szybie uchylonego okna baraku przy dźwiękach serii wystrzałów. Obserwujemy m.in. pokryty śniegiem teren oraz stojący obok drutów amerykański czołg. Wprowadzone zostają plansze z napisami. Następnie dokonuje się zmiana nastroju. Odgłosy wystrzałów są zastąpione przez Cztery pory roku Antonia Vivaldiego, w kolejnych kadrach pojawia się grupa ubranych w pasiaki więźniów biegnących w kierunku płotu. Zatrzymują się przy nim na chwilę, by następnie przy pomocy kilofów, łopat i motyk przerwać barierę oraz wybiec w pole. Potykają się w śniegu, podskakując i tańcząc, śmieją się, obejmują siebie i żołnierzy, a następnie... zdyscyplinowanym truchtem wracają za druty, do obozu. Tam odbywają się obrzędy wyzwoleńcze - palenie pasiaków, wybijanie okien baraków, kompulsywne jedzenie, wreszcie rytualny mord na obozowym kapo. W otoczeniu politycznych kłótni, odradzających się animozji i zawiści oraz zabiegów przede wszystkim o to, by się najeść, a właściwie nażreć do syta, toczyć się będzie akcja filmu i opowieść o tragicznej miłości młodego Tadeusza (gra go Daniel Olbrychski) i Żydówki Niny (debiutująca na ekranie Stanisława Celińska). Jak pisał w bardzo osobistej recenzji, właściwie eseju, Melchior Wańkowicz, ów „uścisk miłosny wyzwalających się, bo nie wyzwolonych, chłopca i dziewczyny" można potraktować jako symbol odradzania się z poniżenia ${ }^{1}$. Odrodzenia, dodajmy, które nigdy się nie dokona.

O tym właśnie będzie ten szkic - o pozornym uwolnieniu, swoistej niemożności wyjścia z obozu, o zarażeniu lagrową moralnością, zagubieniu i przywiązaniu do hurapatriotycznych rytuałów. O zapisanej w literaturze kondycji osób

* Dr Bartłomiej Krupa; Instytut Badań Literackich PAN, Zespół Badań nad Literaturą Zagłady; ul. Nowy Świat 72, 00-330 Warszawa; bartlomiej.krupa@ibl.waw.pl.

${ }^{1}$ M. Wańkowicz, ,,Sercem gryze”, „Kultura” [Warszawa] 1970, nr 40, s. 5. 
zamkniętych w obozach dla dipisów (displaced person) w Niemczech tuż po wojnie. Szkic nie rości sobie praw do kompletnego, całościowego omówienia zagadnienia. $\mathrm{Z}$ racji ograniczeń objętościowych stanowi raczej zaproszenie do tematu, wskazanie głównych problemów, niż wyczerpujący opis.

W polskiej literaturze przedmiotu niewiele o życiu więźniów-dipisów napisano, mimo iż wedle szacunków chodziło o około siedem milionów osób. Ich kondycję dobrze oddaje tytuł książki Andreasa Lembecka - Wyzwoleni, ale nie wolni ${ }^{2}$. Dziejom zamkniętych w obozach dla dipisów pojedyncze teksty poświęciła Katarzyna Person ${ }^{3}$. Publicystyką w obozach zajmowała się Jolanta Chwastyk-Kowalczyk ${ }^{4}$. O losach społeczności wysiedleńców w Niemczech, przede wszystkim wojskowych, pisał Arno Giese w książce Polskie orly nad Renem ${ }^{5}$. Terenem Austrii zajmował się z kolei Andrzej Pilch ${ }^{6}$. Ukazało się też ważne studium Tamar Lewinsky Żydowscy uchodźcy i przesiedleńcy z Polski w okupowanych Niemczech ${ }^{7}$. Badaczka koncentruje się jednak niemal wyłącznie na strefie amerykańskiej oraz brytyjskiej, o strefie francuskiej wspomina jedynie, że znajdowała się tam „bardzo mała i wciąż kurcząca się liczba około tysiąca żydowskich dipisów". Losy uwięzionych/zamkniętych (w przypadku „przesiedlonych" każde określenie staje się ambiwalentne) poznajemy przede wszystkim właśnie dzięki literaturze.

${ }^{2}$ A. Lembeck, Wyzwoleni, ale nie wolni. Polskie miasto $w$ okupowanych Niemczech, przeł. Barbara Ostrowska, Warszawa 2007.

${ }^{3}$ Zob. np. K. Person, ,I I am a Jewish DP. A Jew from the eternal nowhere”. Jews from Poland in displaced persons camps in the occupation zones of West Germany: encounters with Poles and memories of Poland, 1945-1946, „Kwartalnik Historii Żydów” 2013, nr 2, s. 312-318, oraz taż, Szkolenia zawodowe ORT-u w obozach dla DP w Niemczech, Austrii i Wtoszech, „Kwartalnik Historii Żydów” 2010, nr 2, s. 194-206.

${ }^{4}$ Zob. J. Chwastyk-Kowalczyk, Katyń, dipisi, PKPR na łamach polskich czasopism uchodź$c z y c h$, Wydawnictwo Uniwersytetu Humanistyczno-Przyrodniczego Jana Kochanowskiego, Kielce 2011.

${ }^{5}$ A. Giese, Polskie orly nad Renem. Przeklęci i pozbawieni obywatelstwa! Historia, która napisaty niezwykte dramaty ludzkie, Rytm, Warszawa 2013.

${ }^{6}$ Zob. A. Pilch, Losy Polaków w Austrii po drugiej wojnie światowej 1945-1955, Zakład Narodowy im. Ossolińskich, Wrocław 1994.

${ }^{7}$ Zob. T. Lewinsky, Żydowscy uchodźcy i przesiedleńcy z Polski w okupowanych Niemczech, w: Nastęstwa zagłady Żydów. Polska 1944-2010, pod red. F. Tycha i M. Adamczyk-Garbowskiej, Wydawnictwo Uniwersytetu Marii Curie-Skłodowskiej, Żydowski Instytut Historyczny im. Emanuela Ringelbluma, Lublin-Warszawa 2012.

${ }^{8}$ Tamże, s. 100. Na temat polskich więźniów w tej strefie zob. P. Sękowski, Francja wobec polskich uchodźców wojennych i dipisów w pierwszych latach po drugiej wojnie światowej, „Dzieje Najnowsze" 2014, nr 2, s. 71-83. 


\section{Tadeusz Nowakowski}

Bodaj najważniejszym tekstem prozatorskim, którego akcja rozgrywa się w obozie dla displaced persons, jest wydana w 1957 roku w paryskiej Libelli autobiograficzna powieść Tadeusza Nowakowskiego Obóz wszystkich świętych ${ }^{9}$. W rzeczywistości autor przebywał w obozie w Haren-Ems (Maczków) w Niemczech (w pobliżu granicy z Holandią), o którym pisał Lembeck ${ }^{10}$, gdzie nauczał w polskim liceum. Mimo iż powieść zostaje opatrzona notką: „Wszystkie postacie tej powieści są wyłącznie tworami wyobraźni autora i nie mają żadnych określonych prototypów w rzeczywistych osobach. Ewentualne podobieństwa do nich mogą być tylko dziełem przypadku" (s. 4), klimat w obozie oddany jest na tyle dokładnie, znajduje w dodatku potwierdzenie w innych tekstach ${ }^{11}$, iż szybko nabieramy - my czytelnicy - pewności, że ta pełna satyry, groteski, nasycona sarkazmem i elementami pamfletu powieść nie odbiega daleko od rzeczywistości.

Tytuł zaczerpnięty został od nazwy jednego z baraków, którym po wyzwoleniu nadano imiona katolickich świętych (więźniowie nie chcieli numerów, bo kojarzyły się z lagrem), a cały obóz ofiarowano Sercu Jezusowemu „w podzięce za odzyskaną wolność", co początkowo wywołało opór. Jak mówił komendant obozu, major Kosko:

- Jak to? Mamy mieć barak św. Antoniego? Barak „Pod Matką Boską”? Czy to nie bluźnierstwo? Alboż to księdzu nie wiadomo, że nasi łotrzykowie kradną jak kruki, urzynają się samogonem, wypruwają sobie flaki nożem i, za przeproszeniem, pieprzą się na pryczach od świtu do nocy? (s. 18).

${ }^{9}$ Zob. T. Nowakowski, Obóz Wszystkich Świętych, Libella, Paryż 1957. Krajowe wydanie powieści zostało wstrzymane po tym, jak wyszła na jaw współpraca przebywającego na emigracji autora z Radiem Wolna Europa. Gotowy skład książki rozsypano, w prasie zdążyły się już jednak ukazać pierwsze omówienia powieści. Zob. np. J.P. [Julian Przyboś], Świetna powieść, „Przegląd Kulturalny” 1957, nr 20; Z. Starowieyska-Morstinowa, Dwa lata po wojnie, „Tygodnik Powszechny” 1957, nr 21; H. Wandowski, „,Obóz Wszystkich Świętych”, „Tygodnik Zachodni” 1957, nr 51/52; J.J. Lipski, Uczeń klasyków i jego kompleksy, „Twórczość” 1958, nr 2. Pierwsze krajowe, drugoobiegowe wydanie Obozu Wszystkich Świętych ukazało się dopiero w 1989 roku nakładem warszawskiego Pokolenia, a pierwsze oficjalne - w wydawnictwie Czytelnik w 1990 roku. Wkrótce (1991) dokonano także adaptacji teatralnej. Korzystam z przywołanego, pierwszego oficjalnego wydania z 1989 roku. Wszelkie cytaty podaję za tą edycją.

${ }^{10} \mathrm{~W}$ obozie umieszczono 5000 Polaków uwolnionych z obozów pracy i obozów jenieckich. Wśród nich byli powstańcy warszawscy, w tym 1728 kobiet, uczestniczek powstania uwolnionych z obozu w Oberlangen.

${ }^{11}$ Przypomnę, że Tadeusz Nowakowski jest również autorem zbioru opowiadań Szopa za jaśminami (1948), będących wspomnieniami z niemieckich obozów. 
Kondycja zgromadzonych w obozie „niedobitków kacetowych” - ujmując rzecz eufemistycznie - nie należy do najlepszych. „Ludzie koczujący na pobojowisku w kręgu niezagojonych wspomnień i niewygasłych namiętności nie znali, bo po latach okrucieństw znać nie mogli, uczuć tak luksusowych jak wyrozumiałość i wielkoduszność" (s. 8) - mówi narrator, w innym miejscu dodając, że wyłażą z niego „resztki drutu kolczastego”:

- Psychozy jenieckie, zastarzałe nawyki, garb dnia wczorajszego, psychiczne kalectwo większości papenburczyków.

Jakże często widywał na ulicy poważnych, statecznych oswobodzeńców, którzy na widok policjanta zachowywali się jak tropieni złodziejaszkowie: w ostatniej chwili skręcali w najbliższą bramę, znikali za węgłem, szybkim, nerwowym krokiem przechodzili na drugą stronę jezdni. Jeszcze inni, choć ich nikt o to nie prosił, skwapliwie wyjmowali dokumenty osobiste z kieszeni. Zarażeni obozową epidemią przepustek, zaświadczeń, zezwoleń i kart identyczności, legitymowali się z własnej inicjatywy (s. 19).

Nie do pozazdroszczenia jest także aktualnie życie dipisów:

W dwa lata po zakończeniu wojny żywy człowiek, bez wyroku sądu, w kwiecie wieku, siedzi w baraku i nie może się z niego wydostać. Czuł się w zatęchłym Papenburgu jak ryba w akwarium. Międzynarodowe organizacje charytatywne wrzucają rybom do wody po muszce, by nie zdechły. I to wszystko, co człowiek dzisiejszy w swej szlachetności wymyślić może. Z początku trykał głową w szkło, ale rychło spostrzegł, że ściany są z grubego szkła. Teraz leży, śnięty w szlamie, na dnie. Wodorostem przykryty, czeka - nie wiadomo na co. Niby wolny, bo oswobodzony. W istocie zaś więzień, osadzony w baraku „Wszystkich Świętych”.

Cóż za pretensjonalna nazwa! (s. 16-17).

Toteż bohaterowie wściekają się „na nieustającą tymczasowość swej egzystencji” (s. 16) i stopniowo „świerkują” (dziwaczeją, rozklejają się umysłowo; s. 20), popadają w higieniczne fiksacje, wydają absurdalne broszury ,z pogranicza polityki i okultyzmu", kolekcjonują puste puszki po konserwach, wróżą z fusów po kawie lub pasjonują się ruinami.

Pełna ostrej satyry, groteski, sarkazmu powieść przedstawia społeczność polskich dipisów jako ludzi całkowicie zagubionych i zdegenerowanych obozowymi przeżyciami, a jednocześnie kultywujących podniosłe, patriotyczne obrzędy, nieustannie politykujących (starszyzna obozu najpoważniejsze dyskusje toczy w latrynie) i postrzegających świat w czarno-białych barwach. W całym obozie panuje „narodowy masochizm” i ,nagi patriotyzm” - ,ojczyzna podkasała spódnicę i pokazała posiniaczone pośladki” (s. 25). Osadzeni zaś tworzą - jak pisze 
Aleksander Fiut - „polskie piekiełko"12. Stąd ppor. Stefan Grzegorczyk, pseudonim bojowy „Mściciel”, były powstaniec i obozowy nauczyciel historii, który ożenił się z Niemką - Urszulą Heinemann, zostaje uznany za zdrajcę:

- Korabolant! - wołano przed kaplicą.

- Podporucznik-renegat!

- Zhańbił mundur żołnierza polskiego!

- Odgrodził się raz na zawsze od ojczyzny! Przeszedł na stronę odwiecznego wroga!

- Po tym wszystkim, co Niemcy zrobili w Warszawie i w Oświęcimiu, ożenił się ze Szwabką, z taką, za przeproszeniem, szkopską zdzirą! - mówiły zgorszone kobiety w ogonku po chleb. - Nic go ta wojna nie nauczyła!

- Gorszy od volksdeutscha, bo w volksdeutschu chociaż kropla krwi niemieckiej płynie, a on Grzegorczyk, polski Grzegorczyk z dziada pradziada! (s. 9)

- mówią o nim zgorszone kobiety w chustach.

„Świetna powieść” Nowakowskiego - jak nazwał ją w jednej z pierwszych recenzji Julian Przyboś ${ }^{13}$ - stanowi brutalny, acz rewelacyjny językowo, znakomity i przejmujący obraz kondycji psychicznej ocalałych.

\section{Tadeusz Borowski}

W analogicznej jak Nowakowski sytuacji znalazł się po wojnie również Tadeusz Borowski. Pisarz, osadzony po wyzwoleniu z Dachau-Allach w obozie dla dipisów we Freimannie (przedmieścia Monachium) ${ }^{14}$, zawarł swoje przeżycia z tego okresu w niezwykle gorzkim opowiadaniu Bitwa pod Grunwaldem, włączonym do późniejszych wydań Pożegnania z Marią. Właśnie na jego podstawie powstał film Andrzeja Wajdy Krajobraz po bitwie.

Narrator Bitwy pod Grunwaldem - cyniczny poeta Tadek - trafił do gmachu byłych koszar SS, pilnowanych przez żołnierzy amerykańskich: „Pod kamiennymi ścianami koszar, na wąskich pasach zieleńców, między rozwalonymi stertami gnijących śmieci, które wonią zarażały cały dziedziniec, pełzały w górę anemiczne drzewka klonów i szczelnie krzewił się tuż nad betonem kwitnący czerwono

12 Zob. A. Fiut, Polskie piekiełko, „Teksty Drugie” 1991, nr 1/2, s. 169-176.

${ }^{13}$ Zob. J.P. [J. Przyboś], dz. cyt.

${ }^{14} \mathrm{O}$ okresie pobytu pisarza we Freimannie i o powstających wtedy utworach - opowiadaniach, wierszach, pamiętniku czy reportażu poetyckim Koniec wojny - pisze Tadeusz Drewnowski w monografii Ucieczka z kamiennego świata. O Tadeuszu Borowskim, Państwowy Instytut Wydawniczy, wyd. 2, Warszawa 1977, s. 94-101 oraz 233-237. 
żywopłot"15. Przebrany w były mundur esesmański Tadek komentuje swój los następująco:

- Ładnie jest, bracia, na świecie - westchnąłem z udanym smętem - ale cóż, człowieku: siedzisz zamknięty jak za Niemca, przepustki ci na świat nie dadzą, bo nie umiesz się lizać, przez dziurę w murze nie wyjdziesz, bo ustrzelą, wiadomo - häftling. A jak siedzieć? Jak komu syn barana przyniesie albo Niemkę przyprowadzi, to może siedzieć. A ty? Siedź, jak głodno i do domu daleko. Żeby chociaż nie kradli! Byłoby lżej, że wszystkim jednakowa dola... Ale do czasu, do czasu... (s. 259).

Z opowiadania Borowskiego, podobnie jak z powieści Nowakowskiego, wyłania się obraz obozu uchodźców jako krainy tragifarsy - miejsca animozji, cynizmu, skakania sobie do oczu (,nasz Polak, nasz brat, zawsze głupi. W łyżce wody chce utopić brata"; s. 257), przyziemnego życia, w którym najważniejsze jest zapełnienie brzucha i zdobycie tanim kosztem kobiety na noc. Ci, którzy nie przeżyli obozu koncentracyjnego, nie rozumieją ,wyzwolonych”.

On całą wojnę był gdzieś tam w wielkim świecie, co to wiesz - bohaterstwo i Ojczyzna, i trochę Boga. A myśmy mieszkali gdzie indziej, co to brukiew, pluskwy i flegmony. On na pewno jest syty, mnie się chce jeść. On na dzisiejszą uroczystość patrzy pod kątem Polski - ja gulaszu i jutrzejszej postnej zupy. Jego gesty będą niezrozumiałe dla mnie, moje zbyt tuzinkowe dla niego, a obaj sobą troszeczkę pogardzamy (s. 260)

- mówi o arcybiskupie Tadek. Toteż bohater ucieka „od narodowego i boskiego misterium”, „nie buduje [...] fundamentu drzewca sztandaru narodowego, złożonego z ducha poległych i innych" (s. 266). Tymczasem pozostali współosadzeni organizują na tle narodowych waśni nadęte, pełne patriotycznej pompy uroczystości rocznicy bitwy pod Grunwaldem, w czasie których skoszarowani - by użyć frazy samego Borowskiego - „onanizują się Ojczyzną"16. W zakończeniu opowiadania owe uroczystości wieńczy ceremonia palenia słomianych kukieł esesmanów.

Przede wszystkim zaś obóz dla dipisów nie różni się specjalnie od przeżytego niedawno kacetu, w myśl słynnego fragmentu Pożegnania z Marią: „A ja myślę, że po aryjskiej stronie też będzie getto [...]. Tylko nie będzie z niego wyjścia"17.

${ }^{15}$ T. Borowski, Bitwa pod Grunwaldem, w: tenże, Utwory wybrane, oprac. A. Werner, Zakład Narodowy im. Ossolińskich, Wrocław 1991, s. 258. Dalsze cytaty przywołuję za tym zbiorem.

${ }^{16}$ Nawiązuję tu do wiersza Borowskiego *** [Onanizują się Ojczyzną...], w: tenże, Utwory wybrane..., s. 43.

${ }^{17}$ T. Borowski, Pożegnanie z Maria, w: tenże, Utwory wybrane..., s. 148. 
Bohater Bitwy pod Grunwaldem wielokrotnie podsuwa podobną analogię, mówiąc np.: „To jest jeszcze kwarantanna. Ni to kacet, ni to wolność” (s. 270). Z obozu nie można dobrowolnie wychodzić. Za murami jest „świat, do którego puszczano za dobry marsz, za karny meldunek, za sprzątniecie korytarza, za lojalność, za niezłomność, a także za Ojczyznę...” (s. 258). Komentujący ten utwór Andrzej Werner pisał w tym kontekście, że „rzeczywistość obozu dla dipisów jest prostą kontynuacją obozu hitlerowskiego. Ci sami ludzie, te same między nimi relacje - mimo zmienionych okoliczności"' ${ }^{18}$. Uzupełnieniem tego prozatorskiego obrazu może być poezja Borowskiego z okresu monachijskiego, np. pełen jadu wiersz Dary demokratyczne, który przywołam w całości:

Demokracja dała mundur Gestapo, mieszkanie w SS-kasernie, przyoblekła mój młodzieńczy poetycki zapał w ciało żebrzaste, kościste, mizerne.

Demokracja dała wojłoki na czerwiec, ani jednej koszuli. Szczęśliwy jak bóstwo jest człowiek bez koszuli (Andersen). Niezmiernie cieszy się z wszy, pcheł i pluskiew.

Demokracja dała Unrę, w Unrze - piwo i szóstkę chleba na dzień (trzydzieści deko).

Niech żyje demokracja! Dobrze, żeśmy przeżyli, trzeba ślad zostawić tym, co przyjdą, wiekom.

Demokracja dała wszystko, sama nic nie chce, rzekł Churchill: „o ideę bijemy się, nie o zysk”, chciałbym dać demokracji coś... nad czas i przestrzeń, chciałbym dać demokracji w pysk! $!^{19}$

${ }^{18}$ A. Werner, Zwyczajna apokalipsa. Tadeusz Borowski i jego wizja świata obozów, wyd. 2, Czytelnik, Warszawa 1981, s. 188.

${ }_{19}$ T. Borowski, Dary demokratyczne, w: tenże, Pisma w czterech tomach, pod red. T. Drewnowskiego, J. Szczęsnej i S. Buryły, Wydawnictwo Literackie, Kraków 2003, t. 1: Poezja, s. 205. Na temat twórczości poetyckiej Borowskiego zob. J. Szczęsna, Tadeusz Borowski-poeta, Poznańskie Studia Polonistyczne. Seria Literacka, Poznań 2000. 


\section{Jerzy Zagórski}

Dobrym komentarzem do tych literackich zapisów, a zarazem cennym, bo powstałym „na gorąco" świadectwem historii są również reportaże Jerzego Zagórskiego z cyklu $W$ południowych Niemczech, przygotowane na podstawie wrażeń z kilkutygodniowej podróży przez Bawarię jesienią 1945 roku $^{20}$. Kreśli w nich Zagórski obraz ludności zamieszkującej Niemcy jako społeczności podzielonej na pięć kast (Indie w środku Europy). Najwyższą kastę stanowią żołnierze amerykańscy i członkowie oddziałów pomocniczych, niższe kolejno: Bawarczycy, dipisi, robotnicy fizyczni i dawni partyjniacy oraz esesmani. Najniższą kastę, pariasów, stanowią wędrujący przez kraj repatrianci niemieccy. Obozy dla dipisów porównuje Zagórski z jednej strony do rysunku Henry'ego Moore'a, przedstawiającego grupę kadłubów, niby-ludzkich postaci śpiących w tunelu, z drugiej do karykatury Fourierowskich falansterów - wspólnoty równych i wolnych ludzi zamieszkujących budynek w kształcie pałacu, w którego obrębie znajdowałyby się sale do nauki i konsumpcji oraz miejsca pracy i mieszkania.

O UNRRA powiada Zagórski: „Wydaje się jednak, że działalność owej instytucji może być tylko prowizoryczna. Jest to łatanie globu-rekonwalescenta sposobami obliczonymi na efekt doraźny”21, zaś o uchodźcach: „u tych ludzi, rzuconych w dziwaczne warunki, w pokraczną sytuację półwięźnia, półtriumfatora, półpodbitego, półzwycięzcy, sens życia został sprowadzony do paru elementarnych funkcji: jedzenia i snu ze wszystkimi jego akcesoriami [chodzi o seks - przyp. B.K.]"22. O tym ostatnim mówi też Julian Wieciech, były więzień Gross-Rosen i Bergen-Belsen, w rozmowie z Agnieszką Daukszą, zawartej w niedawno opublikowanej książce Klub Auschwitz $i$ inne kluby. Rwane opowieści przeżywców:

Zawieźli nas do Wolfsburga. Trochę inaczej o tym pisałem w mojej książce, jak pani zobaczy, bo ja tam poprzekręcałem pewne zdarzenia niestety. I w Wolfsburgu były takie baraki bez łóżek, bez drzwi, bez okien, bez niczego. I nagromadzili bardzo dużo ludzi. A jakie tam odbywały się orgie, kobiety z mężczyznami, ale nie tylko, koniec świata w tym baraku. Orgie się działy całe noce - i kochali się, i bili się, i w pluskwach taplali. Tak było pluskiew dużo, że spadały na nas jak szarańcza. Jak w nocy leżeliśmy, to ściągaliśmy z nas garściami i pluskwy, i wszy, i wszystko ${ }^{23}$.

${ }^{20}$ J. Zagórski, W południowych Niemczech, w: tenże, Szkice z podróży w przestrzeni i czasie, Wydawnictwo Literackie, Kraków 1962.

${ }^{21}$ Tamże, s. 26.

${ }^{22}$ Tamże, s. 30

${ }^{23}$ A. Dauksza, Klub Auschwitz i inne kluby. Rwane opowieści przeżywców, Słowo/Obraz Terytoria, Gdańsk 2016, s. 109-110. 


\section{Ida Fink}

Ostatni literacki zapis życia w obozie dla dipisów, który chciałbym tu przywołać, pochodzi z twórczości Idy Fink. Koniec wojny zastał pisarkę oraz jej siostrę we wsi Auerbach, niemal na przedmieściach Karlsbadu w Badenii-Wirtemberdze, gdzie autorka Skrawka czasu pracowała u chłopa Emila Denningera - piekarza. Wieś została zajęta 8 kwietnia 1945 roku przez wojska francuskie. Następnie obie siostry - jak relacjonowała Fink dla Instytutu Yad Vashem - trafiły do obozu UNRRA ${ }^{24}$ w pobliskiej miejscowości Ettlingen w rejencji Karlsruhe, oddalonej o kilka kilometrów od Auerbach ${ }^{25}$. W obozie w Ettlingen, u podnóża Schwarzwaldu, Ida i Elza przebywać będą blisko rok, do lutego 1946 roku, wchodząc jako dipiski w skład pokaźnej społeczności „sze’erit hapleta” - tych, którzy uniknęli kataklizmu ${ }^{26}$. Domyślać się jedynie można, że był to dla pisarki okres trudny. Nie znała ani losu ojca, ani losu swojego chłopaka. Zdana była na łaskę amerykańskich władz obozowych. W dodatku status uchodźcy wiązał się z ograniczeniem możliwości opuszczania obozu, a co za tym idzie - z przebywaniem w dużym zagęszczeniu ludzi. W wywiadzie udzielonym po latach Stanisławowi Beresiowi opowiadała, że „był taki krótki okres czasu, zaraz po wojnie, kiedy tych tłumów nie cierpiałam i bałam się ich. Dzisiaj już nie"27. Z pewnością nie był to więc dla pisarki czas idylliczny.

Nie wiemy, na ile sytuacje wspomnianych pisarzy - Nowakowskiego, Borowskiego i Fink - były względem siebie analogiczne. Autorka Skrawka czasu nie opisuje szerzej obozu, wspominając w Podróży jedynie moment otrzymania informacji o swoich bliskich:

I nawet kiedy Martine z UNRRY przyniosła wiadomość i powiedziała: - usiądź, Marishka - a ty pomyślałaś, że skoro każe ci usiąść, to znaczy, że przywozi złą

${ }^{24}$ United Nations Relief and Rehabilitation Administration (z ang. Administracja Narodów Zjednoczonych do Spraw Pomocy i Odbudowy) była organizacją międzynarodową, utworzoną w 1943 r. w Waszyngtonie z inicjatywy USA, Wielkiej Brytanii, Chin i ZSRR, w celu udzielenia pomocy obszarom wyzwolonym w Europie oraz w Azji po zakończeniu II wojny światowej. Jak wskazują autorzy popularnej Historii PRL, prawie 70\% świadczeń na rzecz UNRRA pochodziło z USA. Zob. Prezenty od ,cioci UNRY”, w: Historia PRL, t. 1: 1944-1945, red. J. Cieślewska, New Media Concept, Warszawa 2009, s. 87.

${ }^{25}$ I. Fink, [relacja], Archiwum Yad Vashem, $\mathrm{O}_{3} / 1839$.

${ }^{26}$ Por. D. Michman, On the Definition of ,,She'erit Hapletah”, w: tenże, Holocaust Historiography. A Jewish Perspective. Conceptualization, Terminology, Approaches and Fundamental Issues, Vallentine Mitchell, London-Portland 2003, s. 330. Termin 'sze'erit hapleta' został zaczerpnięty z Biblii (Ks. Rodz. 32:9; Ks. Kr. 19:30-31; Ks. Jer. 31:7), oznacza on ocalałych Żydów - w obozach dla dipisów, żydowskich uchodźców, jak i w ogóle ocaleńców z nazistowskiego kataklizmu.

${ }^{27}$ Blizna pamięci, z I. Fink rozm. S. Bereś, „Kresy” 2005, nr 4, s. 141. 
wiadomość, i posłusznie usiadłaś (w pokoju eks-esesmańskim, który był teraz twoim pokojem, w dawnych koszarach SS, w obozie UNRRY dla dipisów), a Martine po chwili milczenia rzekła wzruszonym głosem: votre pére est vivant, votré pére a survécu... - nawet wtedy ani łzy. Elle est devenue trés pale, mais c'est moi qui avais des larmes aux yeux... Tak samo niedługo potem - wiadomości przyszły niemal równocześnie, jedna po drugiej, jedna dobra, druga zła, obydwie po długich miesiącach oczekiwania - gdy rozerwała kopertę i przeczytała imię Mariana oraz nieznaną jej nazwę Majdanek. Stała przy oknie, za którym rosły sosny w dawnym esesmańskim lasku, madame Durand, sekretarka obozu dipisów, przechodziła pod sosnami i ujrzawszy ją, wesoło pomachała ręką. Majdanek. Nigdy nie słyszała tej nazwy. Wiedziała: Oświęcim, Treblinka, Bełżec. Wiedziała: Bergen-Belsen, Mauthausen, ale nie Majdanek. O Majdanku nie wiedziała ${ }^{28}$.

Nieco światła na okoliczności otrzymania tych informacji oraz powrotu rzuciła siostra pisarki, Elza/Hela, w rozmowie, którą odbyłem z nią 9 marca 2013 r. w Tel Awiwie:

Stefan Aszkenazy (ten pianista, z Belgii, bo jest dwóch Aszkenazych) był bratem wielkiej przyjaciółki mojej matki i potem się kilkukrotnie widzieliśmy, ale on zdążył wrócić do Belgii. Była Belgijka, która pracowała z nami, u Unrowców byliśmy razem, i ona jechała do Belgii. I myśmy ją prosiły, że może on żyje i jak on coś wie o siostrze, to ona będzie wiedziała, co się stało z ojcem. Po jakimś czasie Belgijka wróciła z listem, w którym on pisze: „Kochane Kuzynki [...]”, do nas. On znał bardzo dobrze moją matkę i chciał nas ściągnąc do Belgii, żebyśmy przyjechały. I się bardzo ucieszył, powiedział, że on wie, że ojciec żyje, nie znał tylko adresu. Napisał do swojej siostry i przez nią dostaliśmy, ale była jakaś nieścisłość, oni byli w Gliwicach, a to był Gleiwitz czy coś takiego, ale myśmy myślały, że to jest coś innego, tak że myśmy nie wiedziały. Dopiero później, jak żeśmy wracały transportem do Polski - bo szły transporty po wojnie, do Wrocławia myśmy wróciły. Myśmy nie odnalazły wcześniej nikogo. My jesteśmy ze Wschodu i to już wtedy była Rosja, Ukraina wtedy i my nie mogłyśmy wrócić do domu, dlatego żeśmy szukały. To jak myśmy wracały, to dostałyśmy taką gazetkę z poszukiwaniem ludzi i ogłoszeniami „Poszukuje się...”. I zobaczyłyśmy: „Doktor Ludwik Landau poszukuje swoje córki, mieszka w Kłodzku". Ale bez żadnego innego nazwiska, bez dat, gdzie, jaka ulica - myśmy nie wiedziały. Postanowiłyśmy jechać do tego Kłodzka pierwszym transportem, który wtedy odchodził. I przyjechałyśmy ${ }^{29}$.

${ }^{28}$ Zob. I. Fink, Podróż, wyd. 2, Wydawnictwo W.A.B., Warszawa 2004, s. 257-258.

${ }^{29}$ Rozmowa z Elzą (Helą) z d. Landau, przeprowadzona 9 marca 2013 r. w Tel Awiwie. 
O miesiącach pobytu Idy Fink w Ettlingen wiemy zatem niewiele ${ }^{30}$. Z powodu braku badań na ten temat nie znamy nawet podstawowych danych dotyczących np. struktury demograficznej dipisów w tym rejonie. Dla pozostałych stref charakterystyczna była niemal trzykrotnie większa liczba mężczyzn. „Typowym ocalałym był dorosły mężczyzna. Kobiet było niewiele; dzieci i starcy niemalże nie figurowali w składzie demograficznym pierwszych żydowskich społeczności ocalałych" ${ }^{11}$ - zauważa Tamar Lewinsky. Istotne jest natomiast to, że właśnie w obozie w Ettlingen zrodziła się właściwa twórczość pisarki. Ida Fink wspominała o tym wielokrotnie w wywiadach. W filmie dokumentalnym Roniego Abulafii Ida Fink: Rishumim Le-Korot Hayyim (Ida Fink: Ślady) z 2004 roku na pytanie Uriego Cohena - czy pisała w czasie wojny, pisarka odpowiedziała, że pod koniec, u drugiego bauera wzięła kartkę papieru i napisała jedną linijkę: „Chciałabym, żebyśmy doczekały tu pokoju”, po czym nie dodała do tego ani słowa przez dwa lata. Jej stosunek do Zagłady był bowiem bardzo ostrożny. Bała się dotknąć tematu słowami, więc tego nie robiła. Dopiero później zrozumiała, że potrzebowała dystansu. Najobszerniej o początku swojej twórczości opowiada pisarka w rozmowach z Justyną Sobolewską i Piotrem Szewcem w 2003 roku. Zacytuję obie te rozmowy:

- Pani również późno zaczęła pisać.

- To prawda i nieprawda. Próbowałam już przed wojną. We wczesnej młodości pisałam bardzo złe wiersze. Potem znikła chęć pisania. Przez całą wojnę nie myślałam o tym. Tymczasem ta chęć wróciła zaraz po wojnie, kiedy jeszcze byłam w Niemczech, w obozie Unra. Mieścił się on w dawnej szkole esesmanów. Pewnego dnia nagle spadła na mnie myśl w formie rozkazu: „Pisz o tym, co zaszło”. Chwyciłam papier i pióro i zamknęłam się w pokoju. Siedziałam tam parę godzin. Kiedy wyszłam, było już ciemno, ale kartki pozostały puste. Nie napisałam ani słowa. Wtedy sobie thumaczyłam, że miniony czas jest zbyt bliski, a wszystko, co widziałam, zbyt chaotyczne ${ }^{32}$.

Pamiętam dokładnie chwilę, gdy nagle i niespodziewanie opadły mnie myśli o pisaniu o tym, co było tak niedawno. Zdarzyło się to w pierwszych dniach wolności,

\footnotetext{
${ }^{30} \mathrm{Już}$ po napisaniu tego tekstu dotarłem do nielicznych zachowanych numerów obozowego pisma „Nasz Głos” (pojedyncze egzemplarze znaleźć można w Bibliotece Narodowej oraz Bibliotece Towarzystwa Chrystowego dla Polonii Zagranicznej w Poznaniu). Rzucają one światło na życie codzienne w Ettlingen. Przeczytać również w nich można debiutancki, okolicznościowy, poświęcony obchodom pierwszej rocznicy wybuchu powstania warszawskiego, tekst Idy Fink (!), który opublikowała pod swoim ,aryjskim”, przybranym nazwiskiem - Maria Włoch. Zob. M. Włochowna, Dzień czci i chwały..., „Nasz Głos. Pismo obozu Polaków w Ettlingen, U.N.R.R.A. Team 94" 1945, nr 10, s. 1. Szerzej na ten temat piszę w przygotowywanej monografii pisarki.

${ }^{31}$ T. Lewinsky, dz. cyt., s. 99.

${ }^{32}$ Pisze szeptem, z I. Fink rozm. J. Sobolewska, „Gazeta Wyborcza” nr z 13.05.2003, s. 14.
} 
podczas pobytu w obozie UNRRA - po ucieczce z getta w Zbarażu uratowałyśmy się z siostrą za pomocą aryjskich papierów, jako Polki wysłane na roboty do Niemiec, co po latach opisałam w Podróży. Więc gdy opanowała mnie chęć pisania, wzięłam papier i pióro i usiadłam przy stole. Siedziałam tak kilka godzin. Ale kartki papieru pozostały puste, niesplamione atramentem. Nie napisałam ani słowa. Dopiero później zrozumiałam, że była to obawa przed dotknięciem słowami tego tematu - czas Zagłady był wielkim, bolesnym chaosem przeżyć i doświadczeń. To było zbyt bliskie, zbyt świeże, nadal przerażało. Tak rozpoczął się okres pisania bez pisania, który trwał u mnie kilka lat ${ }^{33}$.

Powyższe wypowiedzi pokazują niezmiernie charakterystyczny dla rozmów Idy Fink element. W poszczególnych wywiadach pojawiają się warianty tych samych opowieści, najwyżej tylko trochę zmienione, uzupełniane drobnymi szczegółami. Wydaje się, iż zacytowane wypowiedzi zaważyły również na jednym z zasadniczych błędów, który będzie ponawiany przy okazji omówień twórczości pisarki. Na przykład Henryk Grynberg w eseju Pokolenie Szoa pisał: ,zasiadła do pisania zaraz po wyzwoleniu, w dipisowskim obozie, i pięć godzin siedziała, lecz nie mogła napisać ani słowa. Później, kiedy rany trochę się zasklepiły, zaczęła pisać, ale tylko w pamięci. Dopiero w Izraelu, gdzie wyemigrowała w 1957 roku, wydobyła z siebie swój łagodny, choć nabrzmiały głos"34. Jeszcze większego zniekształcenia dokonała Marta Rutkowska, pisząc: „Debiut pisarski nastąpił bardzo późno - Fink miała wtedy prawie sześćdziesiąt lat. Pierwszym tekstem, który napisała, było opowiadanie Próg" 35 . Podobna informacja pojawiła się nawet w arkuszu maturalnym w 2005 roku $^{36}$. W istocie debiut pisarski Idy Fink miał miejsce znacznie wcześniej - w 1948 roku $^{37}$, a jego źródeł należy szukać właśnie w obozie dla dipisów.

${ }^{33}$ Ocalić pamięć, z I. Fink rozm. P. Szewc, „Nowe Książki” 2003, nr 5, s. 4.

${ }^{34}$ H. Grynberg, Pokolenie Szoa, w: tenże, Prawda nieartystyczna, wyd. 3, Wydawnictwo Czarne, Wołowiec 2002, s. 282.

${ }^{35}$ M. Rutkowska, Podróże pamięci. Twórczość Idy Fink, w: Proza polska na obczyźnie. Problemy - dyskursy - uzupetnienia, pod red. Z. Andresa, J. Pasterskiego i A. Wal, Wydawnictwo Uniwersytetu Rzeszowskiego, Rzeszów 2007, t. 2, s. 202.

${ }^{36}$ Uczniowie zdający rozszerzony egzamin maturalny z języka polskiego mogli przeczytać: „Ida Fink - ur. w 1921 r. w Zbarażu na Ukrainie; uczyła się we lwowskim konserwatorium. W latach 1941-42 przebywała w getcie; uratowała się, uciekając na aryjską stronę. Od 1957 roku mieszka w Izraelu. Zadebiutowała dopiero jako kobieta blisko 60-letnia, pisząc w języku polskim prawie wyłącznie o doświadczeniach Holocaustu”; dokument ten jest dostępny na stronie internetowej Centralnej Komisji Egzaminacyjnej: http://www.cke.edu.pl/index.php/egzamin-maturalny-left/ arkusze-z-lat-2005-2014 [dostęp 08.10.2014].

37 Jeśli nie liczyć okolicznościowego tekstu z „Naszego Głosu”, pierwszym opublikowanym tekstem literackim był Próg (choć pierwotnie opowiadanie to nosiło tytuł Elza), ujmujący historię siostry pisarki - Heli (Elzy). W przeciwieństwie jednak do tego, co pisze Rutkowska, pierwszy raz opowiadanie ukazało się już w 1948 roku, w interesujących zresztą okolicznościach. Pisarka, dzięki pomocy rodziny z Szanghaju, pojechała do sanatorium dla gruźlików w Szwajcarii i tam miała 


\section{Zamiast zakończenia}

Na koniec warto też wspomnieć o innych autobiograficznych tekstach. Okres życia w obozie dla dipisów często odmalowany był na ostatnich stronach relacji obozowych. Niekiedy autorzy poświęcali mu sporo miejsca. Na uwagę zasługują choćby mało znane wspomnienia Wacława Sternera Gefangeni i dipisi (Warszawa 1979) czy Bytam dipisem (Szczecin 1997) Marii Trzetrzewińskiej-Rosickiej, a także Zanim zasypie piasek ślad. Ich los przestroga i przestaniem Krystyny Leonowicz-Babiak i Zenona Babiaka (Dortmund-Lublin 2005). Wszystkie łączy zapis swoistego doświadczenia, które najlepiej nazwać przedłużeniem życia w obozie. Mimo iż dla niektórych autorów (najwyraźniej dla Borowskiego) okres ten był czasem właściwej inicjacji literackiej, w większości odmalowywany jest negatywnie.

Kiedy przed laty przygotowywałem książkę poświęconą wspomnieniom obozowym, zastanawiałem się nad tym, jaka była kondycja wyzwolonych. Chodzi o moment, gdy więźniowie po odbyciu rytuału przejścia znaleźli się w obozie. Przywykli do walki o miejsce na drabinie hierarchii, przyzwyczajeni do odmiennego biegu czasu i wszechobecnych w ich życiu śmierci i trupów, opuścić muszą lager, by udać się na spotkanie z nieznanym. Doszedłem wtedy do wniosku, że zamknięcie okresu życia w obozie nie kończyło się żadnym rytuałem odczyniającym. Wszelkie uwolnienie okazywało się pozorne, miało charakter przewleczenia. Pisałem:

W Procesie Franza Kafki, bohater - Józef K. - spotyka się z malarzem Titorellim, by uzyskać od niego pomoc. Malarz pyta go, jakiego uwolnienia pragnie: „Istnieją trzy możliwości, mianowicie: prawdziwe uwolnienie, pozorne uwolnienie i przewleczenie". Wydaje się, że pozornego uwolnienia dostępują zwolnieni z obozu i ci, którzy uciekli. Po krótkim czasie znajdują się na wolności, żyją jednak nadal w strachu o własne życie. Przewleczenie spotyka tych, którzy wysyłani są do innych obozów lub idą w „marszach śmierci”, przed nimi jeszcze wiele bólu i cierpienia. Prawdziwe uwolnienie spotyka tylko tych, którzy wyzwalani są na terenie obozu, ci na razie są tak zmęczeni bądź ciężko chorzy, że nie doświadczają tego w pełni. Może jedyne prawdziwe uwolnienie z obozu daje śmierć? Nie dowiemy się tego. Ci, którzy jej dostąpili, nie zostawią bowiem świadectwa ${ }^{38}$.

czas, by pisać. Tam też, we francuskojęzycznej prasie, ukazała się właśnie Elza (tłum. M. Wloch i L. Belleme, „Action” 1948, nr 205).

${ }^{38}$ B. Krupa, Wspomnienia obozowe jako specyficzna odmiana pisarstwa historycznego, Universitas, Kraków 2006, s. 143-144. 
Wszystkie powyższe, dotyczące życia „pomiędzy”, opisy pobytu w obozie dla dipisów ujawniają nie tylko, że kondycja „zarażonych śmiercią” była fatalna, lecz również to, że po przejściu obozu (Nowakowski i Borowski) lub Zagłady (Fink) nie było już powrotu do świata „sprzed”. Nie istniał żaden rytuał odczyniający, zaś rodząca się w obozie twórczość nie dawała ukojenia. Udawanie życia sprzed obozu stawało się karykaturą samego siebie, co doskonale rozumieli wnikliwi obserwatorzy rzeczywistości - Nowakowski, Borowski czy Fink. Pełny opis kondycji uchodźców - tak przecież aktualnej - dopiero jednak przed nami.

\section{Bibliografia}

Blizna pamięci, z Idą Fink rozm. Stanisław Bereś, „Kresy” 2005, nr 4, s. 133-143.

Borowski Tadeusz, Pisma w czterech tomach, pod red. Tadeusza Drewnowskiego, Joanny Szczęsnej i Sławomira Buryły, Wydawnictwo Literackie, Kraków 2003-2005.

Borowski Tadeusz, Utwory wybrane, oprac. Andrzej Werner, Zakład Narodowy im. Ossolińskich, Wrocław 1991.

Chwastyk-Kowalczyk Jolanta, Katyń, dipisi, PKPR na łamach polskich czasopism uchodźczych, Wydawnictwo Uniwersytetu Humanistyczno-Przyrodniczego Jana Kochanowskiego, Kielce 2011.

Dauksza Agnieszka, Klub Auschwitz i inne kluby. Rwane opowieści przeżywców, Słowo/Obraz Terytoria, Gdańsk 2016.

Drewnowski Tadeusz, Ucieczka z kamiennego świata. O Tadeuszu Borowskim, wyd. 2, Państwowy Instytut Wydawniczy, Warszawa 1977.

Egzamin maturalny z języka polskiego. Poziom rozszerzony, 2005 r. Dokument dostępny na stronie Centralnej Komisji Egzaminacyjnej [online]: http:/www.cke.edu.pl/index.php/egzamin-maturalny-left/arkusze-z-lat-2005-2014 [dostęp 08.10.2014].

Fink Ida, Elza, thum. Maria Wloch i Laurence Belleme, „Action” 1948, nr 205.

Fink Ida, Podróż, wyd. 2, W.A.B., Warszawa 2004.

Fink Ida, [relacja], Archiwum Yad Vashem, sygn. $\mathrm{O}_{3} / 1839$.

Fiut Aleksander, Polskie piekiełko, „Teksty Drugie” 1991, nr 1/2, s. 169-176.

Giese Arno, Polskie orty nad Renem. Przeklęci i pozbawieni obywatelstwa! Historia, która napisały niezwykte dramaty ludzkie, Rytm, Warszawa 2013.

Grynberg Henryk, Prawda nieartystyczna, wyd. 3, Wydawnictwo Czarne, Wołowiec 2002.

Historia PRL, t. 1: 1944-1945, red. Joanna Cieślewska, New Media Concept, Warszawa 2009.

J.P. [Przyboś Julian], Świetna powieść, „Przegląd Kulturalny” 1957, nr 20, s. 5.

Krupa Bartłomiej, Wspomnienia obozowe jako specyficzna odmiana pisarstwa historycznego, Universitas, Kraków 2006.

Lembeck Andreas, Wyzwoleni, ale nie wolni. Polskie miasto w okupowanych Niemczech, przeł. Barbara Ostrowska, Świat Książki, Bertelsmann Media, Warszawa 2007.

Lewinsky Tamar, Żydowscy uchodźcy i przesiedleńcy z Polski w okupowanych Niemczech, w: Następstwa zagłady Żydów. Polska 1944-2010, pod red. Feliksa Tycha i Moniki Adamczyk-Garbowskiej, Wydawnictwo Uniwersytetu Marii Curie-Skłodowskiej, Żydowski Instytut Historyczny im. Emanuela Ringelbluma, Lublin-Warszawa 2012, s. 95-121. 
Lipski Jan Józef, Uczeń klasyków i jego kompleksy, „Twórczość” 1958, nr 2, s. 158-162.

Michman Dan, Holocaust Historiography. A Jewish Perspective. Conceptualization, Terminology, Approaches and Fundamental Issues, Vallentine Mitchell, London-Portland 2003.

Nowakowski Tadeusz, Obóz Wszystkich Świętych, Libella, Paryż 1957.

Nowakowski Tadeusz, Szopa za jaśminami, Polish Press Agency (Światopol), Londyn 1948.

Ocalić pamięć, z Idą Fink rozm. Piotr Szewc, „Nowe Książki” 2003, nr 5, s. 4-5.

Person Katarzyna, „I am a Jewish DP. A Jew from the eternal nowhere”. Jews from Poland in displaced persons camps in the occupation zones of West Germany: encounters with Poles and memories of Poland, 1945-1946, „Kwartalnik Historii Żydów” 2013, nr 2, s. 312-318.

Person Katarzyna, Szkolenia zawodowe ORT-u w obozach dla DP w Niemczech, Austrii $i$ Wtoszech, „Kwartalnik Historii Żydów” 2010, nr 2, s. 194-206.

Pilch Andrzej, Losy Polaków w Austrii po drugiej wojnie światowej 1945-1955, Zakład Narodowy im. Ossolińskich, Wrocław 1994.

Piszę szeptem, z Idą Fink rozm. Justyna Sobolewska, „Gazeta Wyborcza” nr z 13.05.2003, s. 14.

Rutkowska Marta, Podróże pamięci. Twórczość Idy Fink, w: Proza polska na obczyźnie. Problemy - dyskursy - uzupetnienia, pod red. Zbigniewa Andresa, Janusza Pasterskiego i Anny Wal, Wydawnictwo Uniwersytetu Rzeszowskiego, Rzeszów 2007, t. 2, s. 200-214.

Sękowski Paweł, Francja wobec polskich uchodźców wojennych i dipisów w pierwszych latach po drugiej wojnie światowej, „Dzieje Najnowsze” 2014, nr 2, s. 71-83.

Starowieyska-Morstinowa Zofia, Dwa lata po wojnie, „Tygodnik Powszechny” 1957, nr 21, s. 6.

Szczęsna Joanna, Tadeusz Borowski - poeta, Poznańskie Studia Polonistyczne. Seria Literacka, Poznań 2000.

Wandowski Henryk, ,,Obóz Wszystkich Świętych” „Tygodnik Zachodni” 1957, nr 51/52, s. 5-6.

Wańkowicz Melchior, ,, Sercem gryzę”, „Kultura” [Warszawa] 1970, nr 40, s. 5.

Werner Andrzej, Zwyczajna apokalipsa. Tadeusz Borowski i jego wizja świata obozów, wyd. 2, Czytelnik, Warszawa 1981.

Włochowna Maria [właśc. Fink Ida], Dzień czci i chwały..., „Nasz Głos. Pismo obozu Polaków w Ettlingen, U.N.R.R.A. Team 94" 1945, nr 10, s. 1.

Zagórski Jerzy, Szkice z podróży w przestrzeni i czasie, Wydawnictwo Literackie, Kraków 1962.

Bartłomiej Krupa

\section{DPs camps - literary records of life „in between” experience Invitation to the topic}

(Summary)

This article is a preliminary attempt to read the condition of survivors - those who were imprisoned in the displaced persons camps in occupied Germany just after the war. In this context author considers Tadeusz Nowakowski's novel Obóz Wszystkich Świętych (Camp of All Saints), full of satire, grotesque and thoroughly soaked with sarcasm. The addition to Nowakowski's vision is Tadeusz Borowski's short story Bitwa pod Grunwaldem (Battle of Grunwald), as well as his poems from this time, e.g. Demokratyczne dary (Democratic Gifts), and also Jerzy Zagórski's reports $W$ poludniowych Niemczech (In Southern Germany), where the camps for DPs are compared to Henry Moore's anthropomorphic figures sleeping in the tunnel. Separate reflections are 
devoted to the fate of Ida Fink, Shoah survivor, who was imprisoned in the Ettlingen camp. The writer mentions this time in the novel Podróż (Travel) and the interviews. Textual analyzes lead the author of the article to the conclusion that the narratives are proof of the inability to experience peace of mind in the time of freedom and generally the inability to return to pre-war times.

Keywords: Polish literature; DPs camps; survivors; Tadeusz Nowakowski; Tadeusz Borowski; Jerzy Nowakowski; Ida Fink; rites de passage 